\title{
Mirrors for Princes: Genuine Byzantine Genre or Academic Construct?
}

\author{
Hana Coufalová Bohrnová
}

\begin{abstract}
The term 'Mirrors for Princes' occurs in commonly used handbooks of Byzantine literature $(\mathrm{H}$. Hunger). It denotes highly elaborated advisory works addressed to noble young men or even future emperors to instruct them on certain aspects of human conduct and on how to reign. This term, mentioned for the first time by Godfrey of Viterbo in the $12^{\text {th }}$ century and imported by modern scholars from the literature of the western Middle Ages into the Byzantine milieu, was never used by the Byzantines themselves. Not only the foreign origin of the term, but also significant differences among particular writings classified as 'Mirrors for Princes' with respect to their literary form, language register, style, content, or purpose have made recent scholars question the application of this genre to Byzantine literature. Three main attitudes or approaches have arisen: the complete rejection of the term (P. Odorico); a search for new criteria enabling a more reasonable genre taxonomy (M. Mullett, Ch. Roueché, S. Papaioannou); and the formation of sub-categories within this genre to create more homogenous groups of literary works (G. Prinzing, D. Angelov).

The presented paper pursues two main aims. The first is to describe the development of the application of the genre 'Mirrors for Princes' to Byzantine literature in modern scientific works; the second, after defining recent general trends in scholarly approaches to Byzantine literature, is to judge the impact of these approaches on the criteria of genre taxonomy with respect to this particular genre.
\end{abstract}

\section{Keywords}

Mirrors for Princes; Byzantine literature; Byzantine literary theory

A preliminary version of this paper was presented at the Oxford University Byzantine Society's $18^{\text {th }}$ International Graduate Conference entitled Trends and Turning-Points: Constructing the Late Antique and Byzantine World (c. 300 - c. 1500). 


\section{Introduction}

Didactic literature has a long tradition in the Byzantine milieu. Besides collections of famous sayings, such as florilegia, gnomologia, and centos, the advisory tone can also be detected in edifying readings and in many historiographical, panegyric, and narrative writings. These works contain an unchanging set of pieces of advice related to both the private and public lives of human beings performing particular roles in society. It is no surprise that passages dedicated to the good and bad rule are also included in this advisory set. They instruct the reader about several key topics, such as the relation of the ruler to God or Christ, the relationship between the ruler and his subjects, the choice of intimates and officials, the rejection of flatterers, and the endeavor to achieve cardinal virtues, i.e. prudence, justice, temperance, and courage, usually presented together with philanthropy and piety. Some optional topics also appear according to the writer's personal interests, e.g. the avoidance of drunkenness, the need for education, the treatment of neighbors, the importance of a noble origin or impressive appearance, and instructions concerning the administration of the empire and military campaigns.

These advisory writings are denoted as Mirrors for Princes by scholars. The aim of this paper is to analyze in detail the legitimacy of this term in the Byzantine milieu as well as its application in contemporary literary handbooks or bibliographies, and, on the grounds of this analysis, to identify the development of the scholarly approach to the genre taxonomy of Byzantine literature. ${ }^{1}$

\section{Bringing the term Mirrors for Princes into Byzantine Literature}

The term Mirrors for Princes, borrowed from western writings of the medieval period, was brought into the theory of Byzantine literature by Karl Krumbacher in his seminal book Geschichte der byzantinischen Litteratur von Justinian bis zum Ende des oströmischen Reiches, ${ }^{2}$ without any explanation of genre classification, to denote well-elaborated advisory writings, predominantly constituting moral and practical instructions dedicated to the future or current ruler. The natural application of this term was based on the fact that the contents (cardinal virtues, care for subjects, struggles against enemies etc.) and motives (the emperor as a philosopher, as the living law or as a terrestrial Christ) of such writings

1 This paper is dedicated solely to the conception of the genre Mirrors for Princes in Byzantine literature. For approaches to this genre in different literary milieux and for further bibliography, see e.g. Anton (1968); Hadot (1972: pp. 555-632); Anton (2006); Jónsson (2006); Lachaud \& Scordia (2007); Grimmer \& Blaydes \& McQueen (unpublished).

2 Krumbacher (1897: pp. 456-457). Presenting writings ranked by later scholars among Mirrors for Princes, K. Krumbacher partially followed the pattern of genuine Byzantine genre classification. While he con-

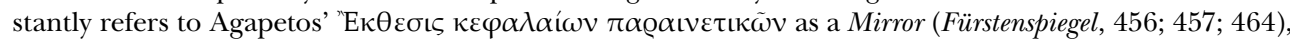

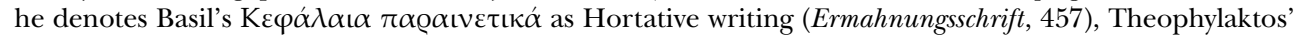

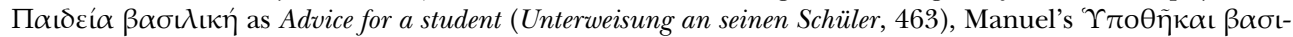

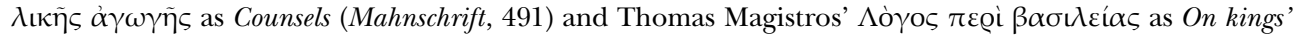
duties (Studie über die Pflichten des Königs, 549). 
from the Western and Byzantine literary milieux were nearly the same. Nevertheless the use of the term Mirrors for Princes is not identical in both literatures. This term, used for the first time by the Staufian chronicler Godfrey of Viterbo in his work Speculum regum dedicated to his imperial patron Henry VI., was adopted by Western medieval writers from the $12^{\text {th }}$ century, while it never occurred in Byzantine literature, ${ }^{3}$ where educative texts presenting advice for the recently crowned emperor or successor to the throne

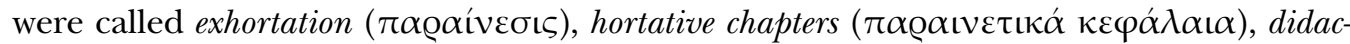

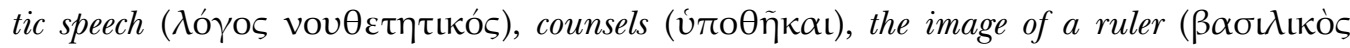

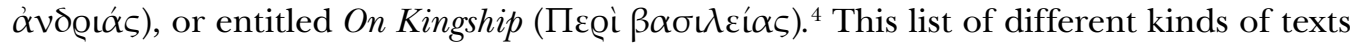
shows that the Byzantines themselves were aware of a significantly greater formal diversity of educative texts dedicated to rulers than their Western counterparts. ${ }^{5}$

The first attempt to define Mirrors for Princes as a genre existing in Byzantine literature, made by H. Hunger ${ }^{6}$ and W. Blum, ${ }^{7}$ was based on the common distinctive features of certain works, e.g. a noble addressee, predominantly gnomic content, political topicality, and inspiration from Isocrates' speech $A d$ Nicoclem and Pseudo-Isocrates' speech $A d$ Demonicum. ${ }^{8}$ After collating a group of writings complying with these criteria, W. Blum applied to them Eberhard's (working) definition originally intended for Western works, describing Mirror for Princes as closed work presenting in great complexity fundamental advice for a ruler, or exhortations for the proper conduct of a ruler considering his special status. There is a personal relationship between the writer and the addressee. ${ }^{9}$ The construction of a usable definition and the existence of several common characteristics justified, from his point of view, the existence of the genre Mirrors for Princes in the Byzantine milieu.

Regrettably, the majority of writings classified as Mirrors for Princes do not comply simultaneously with all the characteristics and Eberhard's definition. In contrast, some other works fulfilling these criteria are not traditionally numbered to this genre. Furthermore, the heterogeneity of this genre group is grounded in the different purposes and formal characteristics of writings, categories initially neglected by scholars. This can be easily demonstrated by the comparison of two works traditionally counted among Mirrors for Princes, the Ekthesis ${ }^{10}$ by Deacon Agapetos, dedicated to the emperor Justinian I, and the Letter of Patriarch Photios of Constantinople to Khan Boris of Bulgaria. ${ }^{11}$ The works have completely different structures. Agapetos' work is in the form of 72 short chapters,

3 Berges (1938); Hadot (1972: p. 556); Blum (1981: pp. 1-5).

4 Giannouli (2009: p. 120).

5 Hadot (1972: p. 616).

6 Hunger (1978: pp. 157-165).

7 Blum (1981).

8 Leonte (2012: p. 168).

9 "Ein Fürstenspiegel ist ein geschlossenes Werk, das mit dem Zweck der grundsätzlichen Wissensvermittlung oder Ermahnung möglichst vollständig das rechte Verhalten des Herrschers im Blick auf seine besondere Stellung erörtert; dabei liegt meist eine persönliche Beziehung zum Herrscher zugrunde.” Eberhardt (1977: pp. 280 and 678).

10 Agapetos (Riedinger 1995).

11 Photios (Laourdas \& Westerink 1983). 
whereas Photios' counsels are formulated under the letter as unequally long teachings supplemented with ecclesiastical history. Neither of them reflects the contemporary political situation. While the activities of Photios have been researched in detail, there is very little known about Agapetos' life; thus, in the latter case, the relationship between the writer and recipient cannot be determined. The incentive to compose each work remains unclear, as well as their reception by the addressee.

\section{The attempt to create more homogenous sub-groups}

Many scholars have concerned themselves with the diversity of writings numbered among the genre group Mirrors for Princes, adopting various approaches to the problem. Some researchers decided to ignore such heterogeneity, because it did not have a further impact on the topic of their research, e.g. E. Barker, I. Čičurov, I. Ševčenko or W. Hörandner. ${ }^{12}$ Others chose only one characteristic common to all works belonging to the Mirrors corpus, e.g. K. D. S. Paidas, who dedicated the two volumes of his Byzantine Mirrors for Princes of the Early and Late Period ${ }^{13}$ to a comparison of motives and symbols related to Byzantine political theory that occur simultaneously in all writings discussed. Other scholars mentioned only briefly the difficulties of defining the genre Mirrors for Princes in the Byzantine milieu, ${ }^{14}$ whereas others preferred to formulate their own definition, e.g. A. Giannouli, who, under the term Mirror for Princes, understands an independent form of advisory writing dedicated to living ruler. ${ }^{15}$

Other scholars, aware of the genre's inconsistency, attempted to divide it into more homogenous sub-groups. In spite of this, however, they did not question the existence of Mirrors in Byzantium or the main distinctive features of the genre, mostly because the use of the term was enrooted in Byzantine literary history. ${ }^{16} \mathrm{H}$. Hunger, grounding his division on literary forms, divided Mirrors into short gnomic and more discursive writings. ${ }^{17}$

G. Prinzing also based his taxonomy on formal characteristics and suggested expanding the Mirrors' corpus with texts embedded in other writings. Therefore, G. Prinzing classified Mirrors as independent works (selbstständig) and texts incorporated into other writings (integriert), modifying Eberhard's definition to correspond to his own conception. ${ }^{18} \mathrm{He}$ also emphasized that without thorough analysis of both independent and incorporated Mirrors, neither the text form nor the content, nor the reasons behind the composition of such writings or their purpose, can be clarified..$^{19}$ Thus "purpose" was

12 Barker (1957); Čičurov (1985: pp. 33-45); Ševčenko (1978: pp. 3-44); Hörandner (2009: pp. 103-114).

13 Paidas (2005; 2006).

14 Angelov (2007: pp. 184-197); Leonte (2012).

15 Giannouli (2009: pp. 119-129).

16 "Die Bezeichnung Fürstenspiegel [...] mag hier wegen ihres traditionellen Gebrauchs in der Sekundärliteratur auch für den byzantinischen Bereich ihren Platz finden.” Hunger (1978: p. 157).

17 Hunger (1978: pp. 158-165).

18 "Ein Fürstenspiegel ist ein in sich geschlossener Text, der [...]." Prinzing (1988: pp. 2-3).

19 "[...] sich ohne systematische Berücksichtigung der integrierten Fürstenspiegel weder die Frage nach 
taken into consideration as a distinctive feature for the classification of advisory works for the first time.

D. Angelov, following in his book Imperial Ideology and Political Thought in Byzantium the traditional categorization based on formal criteria, divided Mirrors for Princes into two sub-groups: speeches (logoi) and gnomoi usually linked by an acrostic. ${ }^{20}$ Other forms such as letters, dialogues, poems, or novels were omitted.

The most complex sub-classification based on the relationship between the author and the addressee and on the writer's main source of inspiration was created by Ch. Roueché, who distinguishes three types of Mirrors: advice to young men (relationship teacher - student, inspiration in Isocrates' Ad Demonicum), advice to rulers (relationship rhetorician - ruler, inspiration in Pseudo-Isocrates' Ad Nicoclem) and the advice of rulers to their sons (relationship father - son, inspiration in the Wisdom of Solomon). ${ }^{21}$

\section{Rejection of the genre Mirrors for Princes}

Attempting to conceive a more precise inner taxonomy for the genre Mirrors for Princes, scholars began to question the whole existence of this genre in Byzantine literature, because, as A. Kazhdan declared, "We are in danger of applying anachronistic criteria and categories to the literature of a people who saw things differently". ${ }^{22}$ G. Prinzing criticized the prevailing approach to the interpretation of Byzantine advisory writings and suggested analyzing Byzantine Mirrors for Princes in the context of other relevant writings of the period..$^{23}$ This proposition was elaborated by K. Karatolios, who, in his recent book dedicated to Mirrors for Princes of the Middle-Byzantine period, ${ }^{24}$ examines each writing in the broader context of the literary activities of its writer as well as other contemporary works and historical events.

The trend of doubting the existence of Mirrors for Princes in Byzantine literature intensified with P. Odorico, who denoted Mirrors for Princes as a non-existent category, an empty vessel without real content, ${ }^{25}$ artificially imported by modern scholars into the Byzantine milieu from Western medieval literature. He further stated that even the best genre taxonomy does not guarantee correct interpretation of a literary work when we do not fully understand the purpose and circumstances of its composition in the context of the literary production of the period or relationship between the author and addressee.

Form und Inhalt byzantinischer Fürstenspiegel insgesamt noch die Frage nach den Ursachen und Anlässen ihrer Abfassung sowie ihrer praktischen Verwendung, um nicht vom 'Sitz im Leben' zu sprechen, hinreichend gründlich klären lassen.” Prinzing (1988: p. 4).

20 Angelov (2007: p. 185).

21 Mullett (2007: pp. 379-383).

22 Kazhdan \& Constable (1982: p. 96).

23 Prinzing (1988: pp. 1-3).

24 Karatolios (2015).

25 "Une catégorie inexistante, véritable boîte à idées vide." Odorico (2009: p. 226). 


\section{The attempt to find new taxonomic criteria}

Bringing inauthentic genre categories into Byzantine literature poses the risk of misinterpreting particular works. It is evident that Byzantine writers were acquainted with literary genres and styles in today's sense of the term, e.g. the distinctions between low, medium, and high styles, and were aware of the formal criteria required by each genre or style. ${ }^{26}$ This is illustrated by many examples of authors apologizing to their readers for not properly fulfilling the genre criteria; e.g. Anna Comnene expresses remorse for her frequent digressions and her emotional presentation of events, incompatible with the rules of historiography. ${ }^{27}$ On the other hand, the Byzantine and modern concepts of the theory of literature differ in many aspects. In the Byzantine context, originality is not more appreciated than the ability to compile or imitate ancient works; there is no distinct line of division between imaginative and educational literature, and writers do not become aware of the break from ancient literary tradition..$^{28}$

For this reason it seems fundamental to base genre classification on criteria natural for Byzantine literature. According to M. Mullett, the most important features for such classification are literary form (dialogue, speech, letter, lyrical form, or narrative form) and content (advisory, didactic, informative, consolatory, entertaining etc.), ${ }^{29}$ because only after consideration of these elements in the broader context of the literature of the period, will the proper genre of each writing be identified.

The method of using only criteria relevant to Byzantine literature was adopted by scholars who base genre taxonomy on the manuscript book culture. As S. Papaioannou states: "[...] We cannot understand Byzantine authorship without examining closely how and why authors enter the world of manuscripts: how they are selected, excerpted, and arranged within books". ${ }^{30}$ The manuscript tradition enables us to judge the extent of the distribution of each text in the time of its composition as well as in the following centuries, the conventional title or its variations, the indivisibility and invariability of the text, or, contrarily, the popularity of some passages that were copied independently. The position of the text in the manuscript and the choice of other texts indicates the purpose of the text. Finally, the comments (scholia) of erudite manuscript copyists and owners are a valuable source of information about the perception of the text by the Byzantines themselves.

It seems clear that functional genre taxonomy requires an expansion of the genuine Byzantine criteria given by M. Mullett (form and content) with other features, since it

26 Mullett (1992: p. 235).

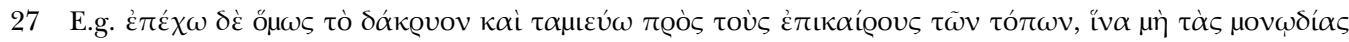

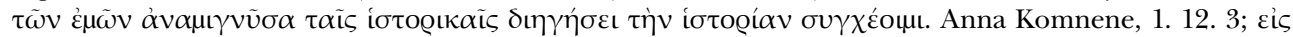

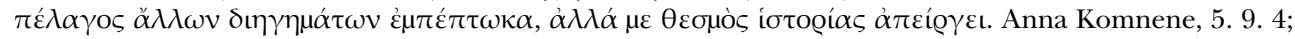

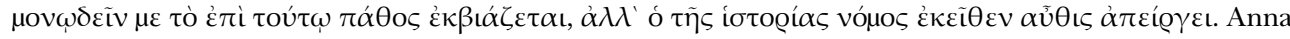
Komnene, 15. 5. 4.

28 Roueché (2009: pp. 129-130).

29 Mullett (1992: pp. 236-237).

30 Papaioannou (2014a: p. 21). Papaioannou broadly explains his approach to Byzantine genre taxonomy on the example of historiography in his other paper. See Papaioannou (2014b). 
is essential to take into consideration also the purpose of the work and the relationship between its author and addressee. While the literary form and content of a text can be usually clearly distinguished, we often lack the information required to define precisely the remaining two categories. Since it is neither possible to apply all the criteria fully defining the genre of Mirrors for Princes, nor to compare such texts to similar works of Western origin, it can be argued that applying the genre Mirrors for Princes to the Byzantine milieu has little justification.

\section{The importance of an individual approach to Byzantine texts}

As was expounded above, though western or modern genre categories such as Mirrors for Princes were unknown to Byzantine authors, these authors distinguished their own genre classification, evident mostly in works belonging to high-style literature. According to this classification, almost all the works in question belong to deliberative, panegyric, or historiographic literature. Although these categories do not differ in their contents and generally present the same list of an ideal ruler's qualities, they evince particularities in their tone, timeline, and approach to the topic. Deliberative writings have a hortatory tone and present the ruler's characteristics as a desired ideal. That is why they are focused on the future, whereas panegyric works, often delivered orally as speeches, aim to draw the listener's attention and for this reason they refer to events from the audience's present or recent past. They have a laudatory tone and depict the emperor's achievements as facts. Within historiographic writings, usually having an informative tone, the authors point to the audience's present or past and put forward the ruler's characteristics also as facts, judging them as either fulfilling or opposing the imperial ideal.

In Byzantium, high-style works were composed according to the rules given by ancient literary theorists and writers. Patterns for various types of orations were created by Menander Rhetor, the $3^{\text {rd }}$ century Greek writer. According to him, a proper laudatory speech addressed to an emperor ( $\beta \alpha \sigma \iota \lambda \iota \kappa o ̀ s ~ \lambda o ́ \gamma o \varsigma)$ required praise of the

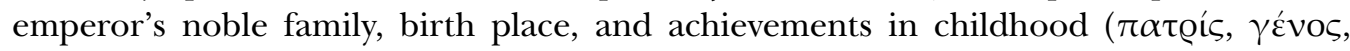

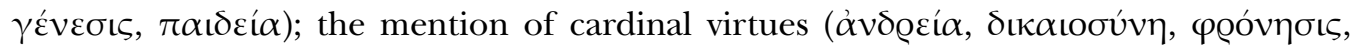
$\sigma \omega \varphi$ Qoбúvๆ) mirrored in his deeds; references to his accomplishments in time of peace

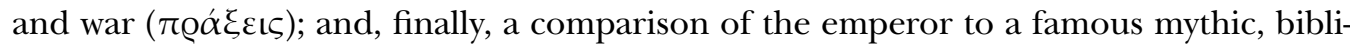

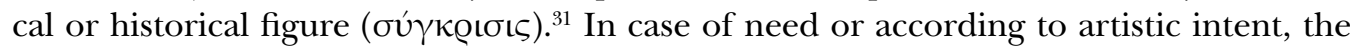
above-described similarity in the contents of deliberative and panegyric works enabled writers to switch masterfully between the Menandrian pattern for laudatory speech and other ancient models for hortatory works, such as Isocrates' speech Ad Nicoclem and Pseudo-Isocrates' speech Ad Demonicum. A salient example of a text incorporating this literary skillfulness is one of the famous Mirrors for Princes entitled Paideia basilike and written by Theophylact of Ohrid for the young prince Constantine Doukas at the end of the $11^{\text {th }}$ century.

31 Menander Rhetor (Russell \& Wilson 1981: pp. 76-94). 
The categorization of Paideia basilike by the abovementioned scholars appropriately demonstrates the impact of different approaches to Byzantine genre classification on the understanding of a specific literary work. K. Krumbacher ${ }^{32}$ perceived Paideia basilike as a deliberative text, as indicated already by his translation of its title as Advice for a student. H. Hunger, ${ }^{33}$ W. Blum,,${ }^{34}$ K. D. S. Paidas, ${ }^{35}$ and K. Karatolios ${ }^{36}$ denoted this writing as a Mirror for Princes containing two independent parts, one panegyric, the other hortatory. E. Barker ${ }^{37}$ concurred with this structure of the work; nevertheless he classified it as a treatise. G. Prinzing ${ }^{38}$ considered Paideia basilike as an imperial speech with an incorporated Mirror for Princes. M. Mullet ${ }^{39}$ and A. Giannouli ${ }^{40}$ interpreted this writing as a homogenous work, a basilikos logos, in which the section praising the recipient's deeds is replaced with a hortatory passage because of Constantine's young age. The rest of the abovementioned scholars did not analyze Paideia basilike in depth in their papers.

Examining Paideia basilike using genuine Byzantine literary criteria, we find that in compliance with the Menandrian pattern for basilikos logos ${ }^{41}$ Theophylact opens his speech with a paean to the young man's native Constantinople and then continues with praise of his inborn qualities and noble parents, mainly his mother. Afterwards, we would expect an appreciation of Constantine's achievements and virtues, but at this point Theophylact adopts a hortatory tone and a future timeline and instructs the young prince in proper royal conduct. Then, Theophylact closes with a brief epilogue. ${ }^{42}$ This substitution was a permissible variation in laudatory writing, as Menander demonstrated in his model birthday speech $(\gamma \varepsilon v \varepsilon \theta \lambda \iota \alpha \kappa o ̀ \varsigma \lambda o ́ \gamma o \varsigma) .{ }^{43}$ For this reason, unlike the abovementioned scholars, we cannot consider this modification a change of genre, a disrup-

32 Krumbacher (1897: p. 463).

33 Hunger (1978: pp. 161-162).

34 Blum (1981: p. 44).

35 Paidas (2005: pp. 29-30).

36 Karatolios (2015: pp. 121-123).

37 Barker (1957: pp. xiii, 145-146).

38 Prinzing (1988: pp. 24-25).

39 Mullett (1996: p. 365); Mullett (2013: p. 255).

40 Giannouli (2009: pp. 124-125).

41 There is no evidence that Theophylact directly used books by Menander or some other suitable textbooks as models for his orations. Nevertheless, patterns for imperial speeches were very similar in all textbooks used by the Byzantines.

42 The structure of Paideia basilike is as follows: Opening (179.1-20, 181.1), praise of Constantinople (181.221), praise of Constantine's natural qualities (181.22-23, 183.1-21, 185.1-8), praise of Constantine's parents (185.9-26, 187.1-29, 189.1-30, 191.1-29, 193.1-4), instructions concerning proper imperial conduct (193.4-31, 195.1-7), three good and bad forms of a government (195.8-20), a portrait of a bad ruler (195.21-23, 197.1-26, 199.1-21), a portrait of a good ruler (199.22-30, 201.1-23), trustworthy friends and servants versus flatterers (201.24-26, 203.1-32, 205.1-31, 207.1-4), imperial virtues (207.5-32, 209.1-5), epilogue (209.5-14).

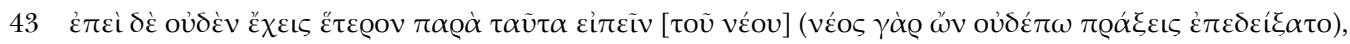

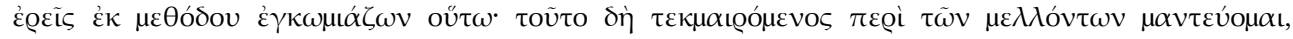

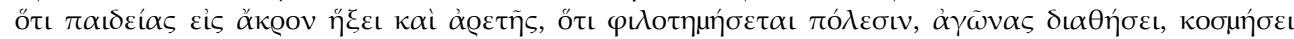
$\pi \alpha v \eta \gamma u ́ \varrho \varepsilon เ \varsigma, \kappa \alpha \grave{~} \tau \dot{\alpha} \tau o เ \alpha \tilde{v} \tau \alpha$. Menander Rhetor, 412.29-31, 413.1-4. 
tion of the ancient model for laudatory oration, or a point where two independent works were connected, but, rather, a permitted alteration within the imperial oration.

To conclude, with this analysis of Paideia basilike, based on genuine Byzantine genre criteria and literary patterns, we show that a text considered by scholars to be a Mirror for Princes, a deliberative work, or the joining of two independent writings can, instead, be a pure laudatory speech. It proves that every divergent genre classification leads to a completely different interpretation of a literary work. For this reason, it is necessary to base the analysis of pieces of Byzantine literature on criteria defined by their authors and not by modern scholars in order to be able to interpret these writings correctly.

\section{Conclusion}

The term Mirrors for Princes was brought into the Byzantine milieu by the first writers of its literary history. Classifying Byzantine literature according to patterns originally created for Western medieval literature, scholars similarly grouped writings corresponding to the definition of Western Mirrors into one genre. Although this method enabled scholars to organize Byzantine texts into a certain logical structure, it evidently evinced weaknesses. Nevertheless, in the 1970s, in his essential book Die hochsprachliche profane Literatur der Byzantiner, H. Hunger considered the genre category of Mirrors too deeply rooted in Byzantine literary history to be completely rejected, although he had objections to the inner homogeneity of this group. His attempt to divide it into more logical subgroups inspired several other scholars. While H. Hunger and G. Prinzing used formal criteria for the partitioning of Mirrors, A. Giannouli and Ch. Roueché took the purpose of the writing and the relationship between the author and the recipient as its distinctive features.

This trend has continued in the last twenty years and resulted in three different approaches represented by P. Odorico, M. Mullett and S. Papaioannou. P. Odorico, after rejecting Mirrors for Princes as a genre category in Byzantine literature, urges careful examination of the circumstances of a work's composition, its true purpose, and its contextualization. M. Mullett suggests employing genuine Byzantine genre classification, in which the term Mirrors for Princes is unknown, and regards these kinds of advisory works as letters, hortatory chapters, speeches, or dialogues. This approach, based on the avoidance of modern criteria when interpreting Byzantine writings, leads to S. Papaioannou's attempt to research manuscripts in order to discover Byzantine's own approach to classifying literary texts.

Making allowances for the examples quoted above, it is evident that the perception of the genre Mirrors for Princes excellently demonstrates general trends in the development of the scholarly approach to Byzantine texts and their classification. While researchers of the late $19^{\text {th }}$ century found it natural to use Western medieval genre taxonomy, completely ignoring the differentness of the Byzantine literary milieu to the Western one, scholars in the $20^{\text {th }}$ century raised objections to this approach and made an effort to analyze Byzantine texts on the grounds of genuine Byzantine criteria. This later attitude resulted in two 
conceptions. In the second half of the $20^{\text {th }}$ century, academics focused on clearly identifiable characteristics, i.e. form and content, while, in the last few decades, they have focused their attention on less explicit features, e.g. the circumstances of composition, the relationship between the writer and addressee, and the contextualization of texts.

This latter trend, bringing augmented interest in genuine Byzantine literary theory and the Byzantine perception of texts, contributed to the creation of a solid theoretical basis, which has culminated in the contemporary classification of Byzantine literature, grounded on the thorough analysis of manuscripts as unique documents reflecting a genuine Byzantine approach to literary texts. In the case of Mirrors for Princes, this means an approach that has no place for such a genre in Byzantine literature.

\section{Bibliography}

\section{Primary sources}

Gautier, P. (Ed.). (1980). Théophylacte d'Achrida: Discours, traités, poésies (Corpus fontium historiae Byzantinae, 16/1). Thessalonique: Association de Recherches Byzantines.

Laourdas, V., \& Westerink, L. G. (Eds.). (1983). Photii patriarcha Constantinopolitani Epistula et Amphilochia (Vol. 1). Leipzig: Teubner.

Reinsch, D. R., \& Kambylis, A. (Eds.). (2001). Annae Comnenae: Alexias (Corpus fontium historiae Byzantinae, 40/1). Berlin: Walter de Gruyter.

Riedinger, R. (Ed.). (1995). Agapetos Diakonos: Der Fürstenspiegel für Kaiser Iustinianos. Athina: Etaireia filon tou laou.

Russell, D. A., \& Wilson, N. G. (Eds.). (1981). Menander Rhetor. Oxford: Clarendon Press.

\section{Secondary sources}

Angelov, D. (2007). Imperial ideology and political thought in Byzantium (1204-1330). Cambridge: Cambridge University Press.

Anton, H. H. (1968). Fürstenspiegel und Herrscherethos in der Karolingerzeit. Bonn: Röhrscheid.

Anton, H. H. (2006). Fürstenspiegel des frühen und hohen Mittelalters. Darmstadt: WBG.

Barker, E. (1957). Social and political thought in Byzantium: from Justinian I to the last Palaeologus. Oxford: Clarendon Press.

Berges, W. (1938). Die Fürstenspiegel des hohen und späten Mittelalters. Stuttgart: Anton Hiersemann. Blum, W. (1981). Byzantinische Fürstenspiegel: Agapetos, Theophylakt von Ochrid, Thomas Magister (Bibliothek der griechischen Literatur; Vol. 14). Stuttgart: Anton Hiersemann.

Čičurov, I. (1985). Gesetz und Gerechtigkeit in den byzantinischen Fürstenspiegeln des 6.-9. Jahrhunderts. In L. Burgmann, M. T. Fögen, \& A. Schminck (Eds.), Cupido legum (Vol. 1; pp. 33-45). Frankfurt am Main: Löwenklau-Gesellschaft.

Eberhardt, O. (1977). Via regia: Der Fürstenspiegel Smaragds von St. Mihiel und seine literarische Gattung. München: Wilhelm Fink. 
Giannouli, A. (2009). Paränese zwischen Enkomion und Psogos: Zur Gattungseinordnung byzantinischer Fürstenspiegel. In A. Rhoby, \& E. Schiffer (Eds.), Imitatio - Aemulatio - Variatio (Vol. 1; pp. 119-129). Wien: ÖAW.

Grimmer, J., Blaydes, L., \& McQueen, A. Mirrors for Princes and Sultans: Advice on the Art of Governance in the Medieval Christian and Islamic Worlds. [Unpublished working paper; retrieved 16. 7. 2016 from http://stanford.edu/ jgrimmer/BGM_final.pdf].

Hadot, P. (1972). Fürstenspiegel. In T. Klauser (Ed.), Reallexikon für Antike und Christentum (Vol. 8; pp. 555-632). Stuttgart: Anton Hiersemann.

Hörandner, W. (2009). Les conceptions du bon souverain dans la poésie byzantine. In P. Odorico (Ed.), «L'éducation au gouvernement et à la vie»: la tradition des «régles de vie» de l'Antiquité au Moyen-Âge: Colloque international - Pise 18 et 19 mars 2005, Autour de Byzance (Vol. 1; pp. 103-114). Paris: De Boccard.

Hunger, H. (1978). Die hochsprachliche profane Literatur der Byzantiner: Philosophie - Rhetorik - Epistolographie - Geschichtsschreibung - Geographie (Vol. 1; pp. 157-165). München: C. H. Beck.

Jónsson, E. M. (2006). Les «miroirs aux princes» sont-ils un genre littéraire? Médiévales, 51, 153166.

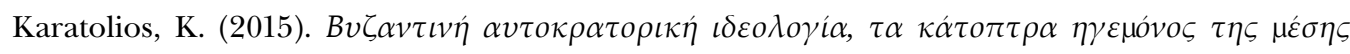

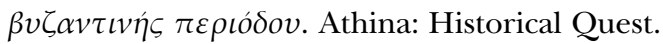

Kazhdan, A., \& Constable, G. (1982). People and Power in Byzantium: An Introduction to Modern Byzantine Studies. Washington: Dumbarton Oaks.

Krumbacher, K. (1897). Geschichte der byzantinischen Litteratur von Justinian bis zum Ende des oströmischen Reiches (527-1453) (2. ed.). München: C. H. Beck.

Lachaud, F., \& Scordia, L. (Eds.). (2007). Le prince au miroir de la littérature politique de l'Antiquité aux Lumières. Mont-Saint-Aignan: Publications des universités de Rouen et du Havre.

Leonte, F. (2012). Rhetoric in Purple: the Renewal of Imperial Ideology in the Text of Emperor Manuel II Palaiologos (unpublished dissertation thesis). Budapest.

Mullett, M. (1992). The Madness of Genre. In A. Cutler, \& S. Franklin (Eds.), Homo Byzantinus: Papers in Honor of Alexander Kazhdan (Dumbarton Oaks Papers, 46). Washington: Dumbarton Oaks.

Mullett, M. (1996). The imperial vocabulary of Alexios I Komnenos. In M. Mullett, \& D. Smythe (Eds.), Alexios Komnenos I: Papers (Vol. 1; pp. 359-397). Belfast: Belfast Byzantine Enterprises.

Mullett, M. (2007). Letters, Literacy and Literature in Byzantium. Aldershot - Burlington: Ashgate.

Mullett, M. (2013). How to criticize the laudandus. In D. G. Angelov, \& M. Saxby (Eds.), Power and subversion in Byzantium: Papers from the 43rd Spring Symposium of Byzantine Studies, Birmingham, March 2010 (Vol. 1; pp. 247-262). Farnham: Society for the Promotion of Byzantine Studies.

Odorico, P. (2009). Les miroirs des princes à Byzance: Une lecture horizontale. In P. Odorico (Ed.), «L'éducation au gouvernement et à la vie»: la tradition des «régles de vie» de l'Antiquité au Moyen-Âge: Colloque international - Pise 18 et 19 mars 2005, Autour de Byzance (Vol. 1; pp. 223-246). Paris: De Boccard.

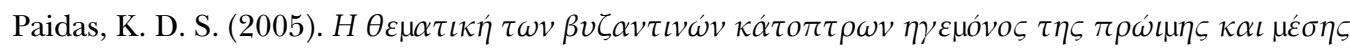

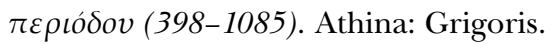

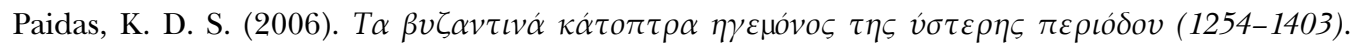
Athina: Grigoris. 
Papaioannou, S. (2014a). Voice, Signature, Mask: The Byzantine Author. In A. Pizzone (Ed.), The Author in Middle Byzantine Literature (Vol. 1; pp. 22-40). Boston - Berlin: Walter de Gruyter.

Papaioannou, S. (2014b). Byzantine historia. In K. A. Raaflaub (Ed.), Thinking, Recording, and Writing History in the Ancient World (The Ancient World: Comparative Histories; Vol. 10; pp. 297-314). Chichester: Wiley-Blackwell.

Prinzing, G. (1988). Beobachtungen zu „integrierten“ Fürstenspiegeln der Byzantiner. Jahrbuch der Österreichischen Byzantinistik, 38, 1-31.

Roueché, Ch. (2009). The place of Kekaumenos in the admonitory tradition. In P. Odorico (Ed.), "L'éducation au gouvernement et à la vie»: la tradition des «régles de vie» de l'Antiquité au Moyen-Âge: Colloque international - Pise 18 et 19 mars 2005, Autour de Byzance (Vol. 1; pp. 129-144). Paris: De Boccard.

Ševčenko, I. (1978). Agapetus East and West: The Fate of a Byzantine „Mirror of Princes“. Revue des études sud-est européennes, 16, 3-44.

Mgr. Bc. Hana Coufalová Bohrnová / h.coufalova@seznam.cz

Department of Classical Studies

Masaryk University, Faculty of Arts

Arna Nováka 1, 60200 Brno, Czech Republic 